\title{
PENGEMBANGAN MODUL MATA KULIAH BERBICARA BERBASIS METODE JIGSAW
}

\author{
Maulidia Tifani Alfin Nur Hardiana ${ }^{1}$, Siti Aisah ${ }^{2}$ \\ ${ }^{12}$ Pendidikan Bahasa Indonesia, FKIP, Universitas Billfath \\ Email: maulidia.tifani@gmail.com
}

\begin{abstract}
This study aims to describe the initial trials of the speaking practice module using the jigsaw method for the Speaking and Learning course. This is a type of research and development $(R \& D)$ using the Borg \& Gall development model which consist of several steps (1) analysis of need; (2) planning; (3) development of product; (4) validation and revision of product; and (5) trial of product. The trial of product was conducted on 12 students. The data was collected by using a product trials questionnaire to get student responses after using the speaking practice module that had been developed. The following are the results of research: (1) the availability of a speaking practice module that has been developed is able to facilitate and motivate students to practice speaking. (2) The product of the development of this speaking practice module consists of public speaking material, this jigsaw method is very helpful for students in understanding a type of speaking and explaining it to their friends in their group. (3) This product has met the product eligibility criteria shown from the results of the student response questionnaire with details on the presentation aspect with the "good" category with a score of 4.00, the material aspect with the "very good" category with a score of 4,3, and the aspect of benefits with a "good" category with a score of 4.00. The results of the validation of the speaking practice module using the jigsaw method are very helpful for students in speaking practice.
\end{abstract}

Keywords: module development, speaking subject, jigsaw method.

Abstrak: Penelitian ini bertujuan untuk mendeskripsikan hasil uji coba awal modul praktik berbicara dengan metode jigsaw untuk mata kuliah Berbicara dan Pembelajarannya. Ini merupakan jenis penelitian dan pengembangan $(R \& D)$ dengan menggunakan model pengembangan Borg \& Gall yang terdiri atas beberapa langkah, yaitu (1) analisis kebutuhan; (2) perencanaan; (3) pengembangan produk; (4) validasi dan revisi produk; dan (5) uji coba produk. Uji coba dilaksanakan pada 12 mahasiswa. Pengumpulan data dilakukan dengan angket uji coba produk untuk mendapatkan tanggapan mahasiswa setelah menggunakan modul praktik berbicara yang telah dikembangkan. Berikut hasil penelitiannya: (1) ketersediaan modul praktik berbicara yang telah dikembangka mampu memfasilitasi dan memotivasi mahasiswa untuk melakukan praktik berbicara. (2) Produk pengembangan modul praktik berbicara ini terdiri atas materi berbicara di depan umum, metode jigsaw ini sangat membantu mahasiswa dalam memahami suatu jenis berbicara dan menjelaskannya kepada teman-teman di kelompoknya. (3) Produk ini telah memenuhi kriteria kelayakan produk yang ditunjukkan dari hasil angket tanggapan mahasiswa dengan rincian pada aspek penyajian dengan kualifikasi "layak" dengan skor 4,00, aspek materi dengan kualifikasi "sangat layak" dengan skor 4,3, dan aspek manfaat dengan kualifikasi "layak" dengan skor 4,00. Hasil validasi modul praktik berbicara dengan metode jigsaw sangat membantu mahasiswa dalam praktik berbicara.

Kata Kunci: pengembangan modul, mata kuliah berbicara, metode jigsaw. 


\section{PENDAHULUAN}

Salah satu alternatif untuk meningkatkan kualitas pembelajaran bahasa adalah bahan ajar. Kondisi di kelas sangat memengaruhi penggunaan bahan ajar. Hal ini bertujuan agar materi dapat diterima dengan mudah oleh peserta didi. Sementara, pembelajaran berbahasa yang mencakup kemampuan menyimak, berbicara, menulis, dan menyimak merupakan salah satu pembelajaran yang harus diajarkan dan dimiliki oleh peserta didik. Ghazali (2010) menyatakan bahwa terdapat empat area keterampilan berbahasa yang tercermin dalam pedoman kecakapan berbahasa American Council on The Teaching of Foreign Language (ACTFL.

Berbicara merupakan keterampilan yang berkaitan dengan kegiatan menerapkan bahasa. Keterampilan berbicara bukanlah datang secara tiba-tiba dan spontan, melainkan harus melalui praktik dan latihan yang intensitasnya tinggi (Azmi, 2019). Melalui keterampilan ini, peserta didik dapat menyampaikan pesan dalam kegiatan komunikasi. Oleh karena itu, peserta didik sangat penting untuk memiliki dan memahami keterampilan ini. Berkaitan dengan hal ini, Program Studi Pendidikan Bahasa Indonesia, FKIP, Universitas Billfath menyusun kurikulum dengan mata kuliah Berbicara dan Pembelajarannya pada semester 2. Mata kuliah ini memiliki orientasi untuk membekali mahasiswa dalam peningkatan kemampuan berbicara khususnya berbicara di depan umum.

Berdasarkan hasil wawancara dan observasi dengan dosen pengampu mata kuliah diperoleh kesimpulan bahwa terdapat beberapa permasalahan yang menjadi penyebab kurang efektifnya pembelajaran berbicara. Pertama, rendahnya minat dan motivasi mahasiswa dalam mengikuti mata kuliah berbicara. Kedua, mahasiswa memiliki rasa percaya diri yang minim karena mereka belum terbiasa berbicara di depan khalayak umum. Ketiga, minimnya penguasaan kosakata atau diksi yang dimiliki. Keempat, belum tersedianya bahan ajar kemampuan berbicara sebagai suplemen pengetahuan mahasiswa. Kelima, mahasiswa belum memiliki pengalaman berbicara di depan khalayak.

Ketidaktersediaan bahan ajar menjadi perhatian khusus untuk meminimalisir permasalahan yang ada. Fakta tersebut mendorong dosen untuk mewujudkan bahan ajar kemampuan berbicara yang sesuai kondisi dan kebutuhan mahasiswa. Banyak metode telah berkembang dalam duni pembelajaran. Salah satu metode yang sedang berkembang dan dapat diintegrasikan dalam bahan ajar adalah metode Jigsaw. Yamin (2013) menyatakan bahwa Jigsaw adalah pembelajaran kooperatif yang setiap anggotanya memiliki tanggung jawab untuk mempelajari bagian materinya masing-masing. Penerapannya adalah setiap anggota kelompok diberikan bagian materi masing-masing yang harus dikuasai kemudian ida sebagai "ahli" sesuai materi bagiannya. Kemudian, seorang "ahli" tersebut harus menyampaikan kepada anggota kelompok lainnya.

Jigsaw merupakan suatu metode pembelajaran yang dilakukan secara berkelompok yang mana dalam kelompok tersebut seluruh anggota bertanggung jawab. Jigsaw itu merupakan kegiatan yang mendorong peserta-pesertanya untuk terbiasa berpikir kritis dari parsial menuju ke universial, melihat korelasi antarbagian dengan hal yang utuh (Warsono \& Haryanto, 2012). Pendapat lain dari Darmuki dan Hariyadi (2019) yang menyatakan bahwa jigsaw merupakan metode pembelajaran kooperatif dan harus ada bahan tertulis sebagai bahan pembelajaran. Beberapa pendapat tersebut dapat disimpulkan bahwa Jigsaw ini suatu metode yang melatih peserta didik untuk selalu aktif dan bekerja dalam kelompok untuk memahami materi secara maksimal.

Hanafiah dan Suhana (2012) menyatakan langkah-langkah metode Jigsaw meliputi

1. Peserta didik membentuk kelompok yang terdiri atas beberapa anggota; 
2. Masing-masing peserta didik dalam suatu kelompok diberikan bagian materi yang berbeda;

3. Materi dibagikan kepada setiap peserta didik dalam suatu tim;

4. Peserta didik dari kelompok yang berbeda dan mendapatkan materi yang sama kemudian bertemu dalam satu tim baru (kelompok ahli) untuk mendiskusikan materi sesuai bagiannya tersebut;

5. Selanjutnya, diskusi kelompok ahli kemudian kembali ke kelompok semula dan berganti mengajarkan tentang materi yang menjadi bagiannya masing-masing serta yang lainnya mendengarkan;

6. Setiap kelompok ahli menyampaikan hasil yang didiskusikan;

7. Pendidik mengevaluasi atau memyampaikan masukan; dan

8. Penutup.

\section{METODE PENELITIAN}

Penelitian ini menggunakan jenelitian dan pengembangan atau Research and Development (R\&D). Model yang digunakan adalah model Borg and Gall. Penelitian dan pengembangan bertujuan untuk mengembangkan, memvalidasi, dan mengujicobakan produk yang digunakan dalam pendidikan (Borg \& Gall, 1983). Produk yang telah dikembangkan adalah modul praktik berbicara dengan metode jigsaw untuk mata kuliah Berbicara dan Pembelajarannya di semester 2.
Prosedur pengembangan Borg \& Gall diadaptasi menjadi lima tahap sebagai berikut.

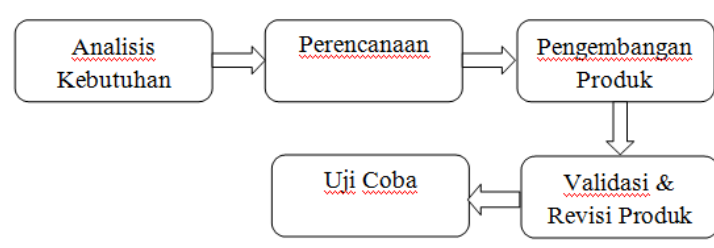

Gambar 1. Tahapan Penelitian

Pengembangan Borg \& Gall yang

Disederhanakan

\section{A. Analisis Kebutuhan}

Langkah pada tahap ini adalah analisis terhadap pelaksanaan praktik berbicara di semester 2. Analisis kebutuhan dilakukan dengan wawancara kepada beberapa mahasiswa dan dosen pengampu mata kuliah.

\section{B. Perencanaan}

Pada tahap ini dilakukan pengkajian rencana pembelajaran semester (RPS), materi, bahan, dan penyusunan draf modul.

\section{Pengembangan Produk}

Tahapan ini melakukan pengelolaan materi dan penyajian modul dengan mengintegrasikan model pembelajaran jigsaw.

\section{Validasi dan Revisi Produk}

Tahapan ini bertujuan untuk mengukur kelayakan awal draf modul. Hasil final dari tahap ini adalah draf modul lebih layak dari sebelumnya. Modul divalidasi oleh dua validator, yaitu pakar/ahli materi dan validator desain (penyajian). Hasil dari masing-masing validator menggunakan persentase dengan kategori berikut.

Tabel 1. Kategori Validitas dan Kelayakan (Sugiyono, 2013)

\begin{tabular}{ccc}
\hline Persentase (\%) & Tingkat Validasi & Krieteria Kelayakan \\
\hline $\mathbf{9 0 - 1 0 0}$ & Produk Sangat Valid & Sangat layak, jadi tidak perlu revisi \\
$\mathbf{7 5 - 8 9}$ & Produk Valid & Layak, jadi tidak perlu revisi \\
$\mathbf{6 5 - 7 4}$ & Produk Cukup Valid & Cukup layak, jadi perlu revisi \\
$\mathbf{5 5 - 6 4}$ & Produk Kurang Valid & Kurang layak, jadi perlu revisi \\
$\mathbf{0 - 5 4}$ & Produk Sangat Tidak & Tidak layak, jadi revisi total \\
& Valid & \\
\hline
\end{tabular}

Modul praktik berbicara dengan metode jigsaw yang telah dikembangkan sudah dapat dimanfaatkan sebagai bahan ajar mata E. Uji Coba

Tahap ini melibatkan 12 mahasiswa semester 2 Program Studi Pendidikan Bahasa kuliah berbicara jikalau memperoleh skor penilaian minimal 70.

Indonesia, Universitas Billfath Tahun Akademik 2019/2020. Dua belas mahasiswa ini terdiri atas empat mahasiswa dengan prestasi 
belajar klasifikasi di bawah rata-rata, sesuai rata-rata, dan di atas rata-rata. Uji coba ini bertujuan untuk mengetahui draf modul yang dikembangkan layak diterapkan atau belum. Hasil final dari tahapan ini adalah modul praktik berbicara yang layak dan dapat dimanfaatkan oleh mahasiswa.
Angket yang telah diberikan mahasiswa berisi tanggapan terhadap modul pada tiga aspek, yaitu aspek penyajian modul, materi dalam modul, dan manfaat modul. Kategori kelayakan modul dipaparkan pada tabel 2.

Tabel 2. Kriteria Kelayakan Modul untuk Mahasiswa (Sugiyono, 2013)

\begin{tabular}{ccc}
\hline Skor & Kriteria & Rentangan Nilai \\
\hline $\mathbf{5}$ & Produk Sangat layak & $4,2<\mathrm{x}$ \\
$\mathbf{4}$ & Produk Layak & $3,4<\mathrm{x} \leq 4,2$ \\
$\mathbf{3}$ & Produk Cukup layak & $2,6<\mathrm{x} \leq 3,4$ \\
$\mathbf{2}$ & Produk Kurang layak & $1,8<\mathrm{x} \leq 2,6$ \\
$\mathbf{1}$ & Produk Sangat kurang & $\mathrm{x} \leq 1,8$ \\
& layak & \\
\hline
\end{tabular}

\section{HASIL DAN PEMBAHASAN}

Uji coba awal yang dilaksanakan di Mata Kuliah Berbicara dan Pembelajarannya yang diikuti oleh 12 mahasiswa. Pemilihan dua belas mahasiswa ini dilakukan oleh dosen pengampu mata kuliah. Dua belas mahasiswa ini terdiri atas empat mahasiswa prestasi belajar rendah, sedang, dan tinggi. Data uji coba awal ini berupa tanggapan mahasiswa terhadap modul praktik berbicara untuk pembelajaran mata kuliah berbicara. Data hasil respons mahasiswa berupa skor yang dituangkan menjadi lima skala. Hasil skor dapat ditunjukkan dalam tabel berikut.

Tabel 3. Ringkasan Hasil Uji Coba Awal

\begin{tabular}{llcccc}
\hline No. & Aspek Penilaian & Skor & $\begin{array}{c}\text { Skor Rata- } \\
\text { rata }\end{array}$ & $\begin{array}{c}\text { Kriteria } \\
\text { Interval Skor }\end{array}$ & Kategori \\
\hline 1. & Penyajian & 36 & 4 & $3,4<\mathrm{x} \leq 4,2$ & Produk Layak \\
2. & Materi & 56 & 4,3 & $4,2<\mathrm{x}$ & $\begin{array}{c}\text { Produk Sangat } \\
\text { layak }\end{array}$ \\
3. & Manfaat & 28 & 4 & $3,4<\mathrm{x} \leq 4,2$ & Produk Layak \\
\hline
\end{tabular}

Pengujicobaan kelompok kecil yang dilakukan pada 12 mahasiswa bertujuan untuk mengumpulkan informasi berupa tanggapan mahasiswa. Tanggapan tersebut digunakan sebagai bahan untuk merevisi modul. Tanggapan mahasiswa terhadap modul ini berfokus pada ketiga aspek, yaitu penyajian, materi, dan manfaat modul. Berdasarkan tabel 3 diketahui bahwa tanggapan mahasiswa terhadap modul praktik berbicara ini dari aspek penyajian mendapatkan rata-rata skor 4 , aspek materi mendapatkan rata-rata skor 4,3 , dan aspek kebermanfaatan modul mendapatkan rata-rata skor 4.
Hasil data pengujicobaan ini sebagai penilaian untuk kepraktisan modul berdasarkan kuesioner respons mahasiswa saat penerapan. Argumn mahasiswa tertarik pada modul ini, yaitu modul praktik berbicara disajikan dalam pembelajaran berkelompok dengan metode jigsaw dan jenis-jenis praktik berbicaranya sesuai dengan yang ada di lingkungan sekitar. Dengan penggunaan metode tersebut, mahasiswa diberikan tanggung jawab materi yang berbeda-beda sesuai bagiannya sehingga meningkatkan minat dan motivasi dalam praktik berbicara. Hal ini sesuai yang dipaparkan Darmuki dan Hariyadi (2019) yang 
memaparkan bahwasanya jigsaw merupakan metode pembelajaran kooperatif dan harus ada bahan tertulis sebagai bahan pembelajaran. Modul praktik berbicara dengan metode jigsaw untuk mata kuliah Berbicara dan Pembelajarannya telah selesai dikembangkan. Produk modul hasil pengembangan yang telah diuji coba ke mahasiswa mendapatkan banyak tanggapan. Tanggapan tersebut meliputi aspek penyajian modul, aspek materi, dan manfaat modul untuk kegiatan perkuliahan. Pada uji coba awal, mahasiswa memberikan respons yang baik dengan kategori skor produk layak dan sangat layak terhadap keseluruhan aspek modul yang telah dikembangkan.

Berdasarkan hasil pengujicobaan awal, terdapat perbedaan hasil praktik berbicara antara sebelum dan sesudah kegiatan pembelajaran menggunakan modul praktik berbicara dengan metode jigsaw. Perbedaan tersebut menunjukkan bahwa modul yang dikembangkan efektif untuk digunakan dalam praktik berbicara. Hal ini sejalan dengan Mudlofar (2012) yang memaparkan bahwasanya segala hal berkaitan dengan bahan untuk memfasilitasi kegiatan belajar mengajar disebut sebagai bahan ajar.

Berdasarkan kajian akhir di atas, dapat dinyatakan bahwa modul praktik berbicara dengan metode jigsaw untuk pembelajaran praktik berbicara telah disusun dan diujicobakan di kelas. Modul praktik berbicara tersebut merupakan modul yang layak dimanfaatkan dan diterapkan untuk kegiatan pembelajaran. Adapun hasil final produk ini adalah modul praktik berbicara yang terdiri atas beberapa jenis berbicara dan dicetak dalam bentuk softcover. Hal ini sejalan dengan Prastowo (2015) yang menyatakan bahwa bahan ajar dibedakan menjadi empat jenis, yaitu bahan ajar interaktif, pandang-dengar, dengar, dan cetak.

Berdasarkan pengujicobaan awal modul, dapat dipaparkan bahwa produk layak diterapkan sebagai bahan ajar mata kuliah Berbicara dan Pembelajarannya untuk membantu kegiatan praktik berbicara pada materi jenis-jenis berbicara. Akan tetapi, terdapat beberapa tanggapan dan saran yang menunjukkan bahwasanya terdapat beberapa bagian dari modul yang perlu direvisi. Oleh karena itu, peneliti mencantumkan jenis-jenis berbicara di depan umum yang seringkali digunakan dalam lingkungan sekitar. Di bawah adalah tampilan materi antara sebelum dengan sesudah diperbaiki.

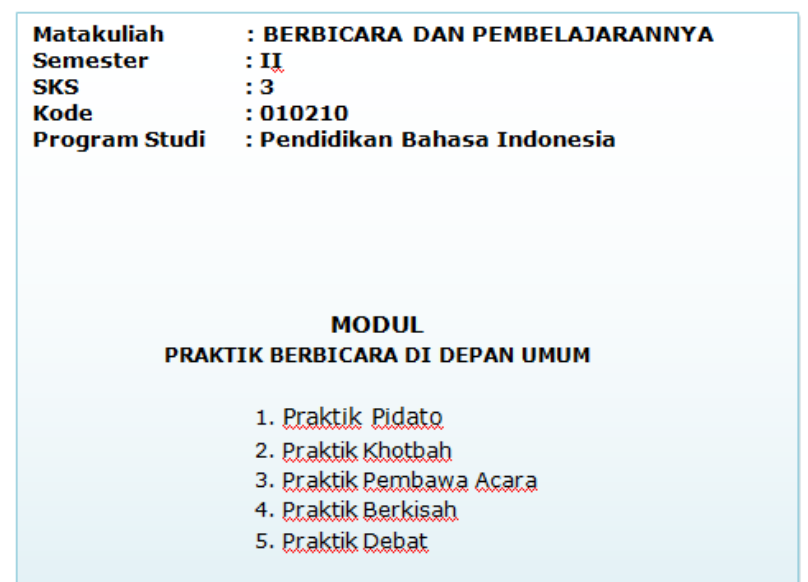

Gambar 2. Tampilan Jenis Berbicara sebelum Direvisi 


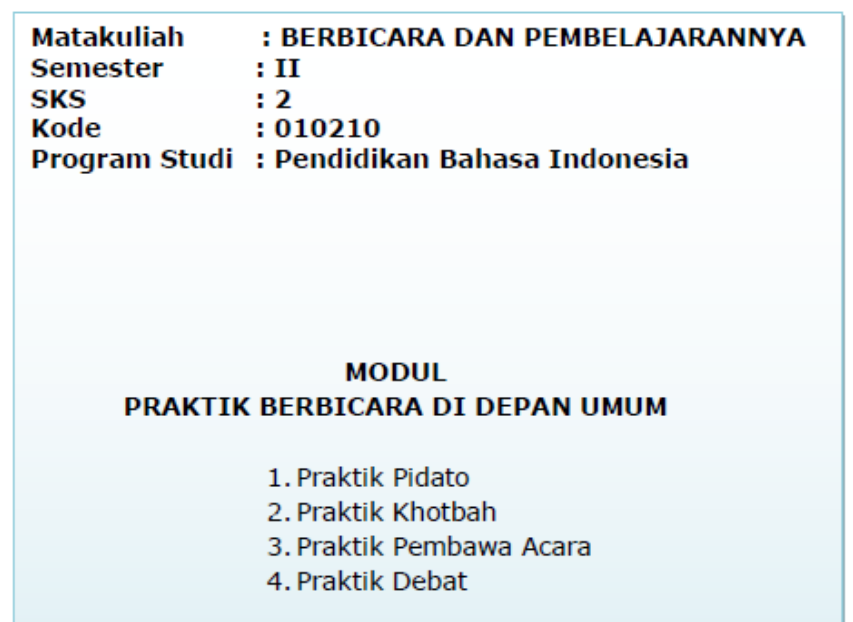

\section{Gambar 3. Tampilan Jenis Berbicara setelah Direvisi}

Kedua, menambahkan prosedur kompetensi yang diharapkan, indikator, pembelajaran agar mahasiswa lebih mudah metode, dan waktu. Selanjutnya, peneliti dalam mengikuti pembelajaran dengan menambahkan prosedur pembelajaran. Di memanfaatkan modul praktik berbicara. bawah ini tampilan antara sebelum dengan Sebelumnya, poin-poin yang ada terdiri atas seusai direvisi.

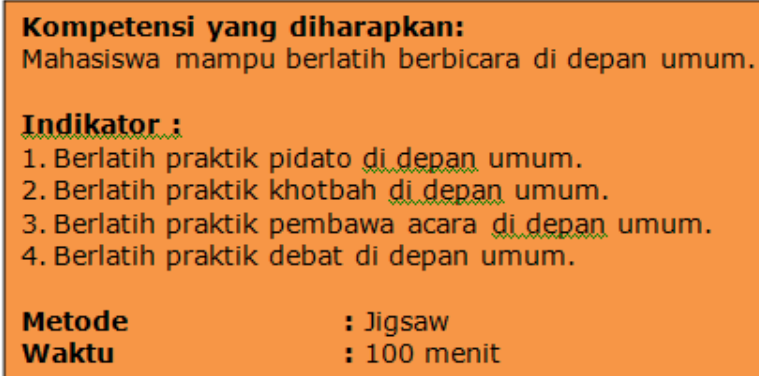

Gambar 4. Tampilan Kompetensi sebelum Direvisi

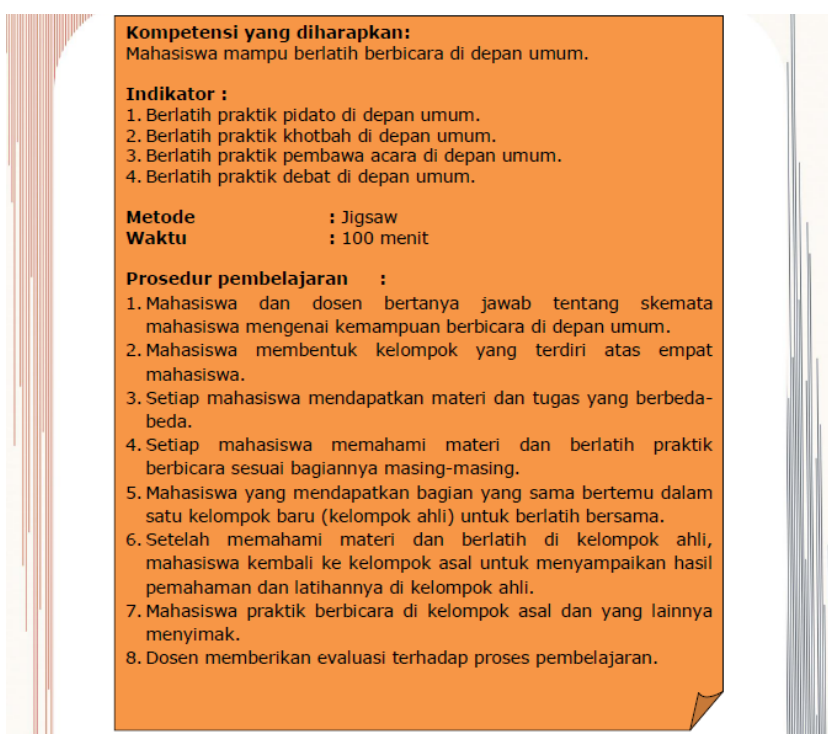

Gambar 5. Tampilan Kompetensi seusai Direvisi 
Penelitian ini menghasilkan Modul Praktik Berbicara dengan Metode Jigsaw untuk pembelajaran Mata Kuliah Berbicara dan Pembelajarannya di Program Studi Pendidikan Bahasa Indonesia, Universitas Billfath. Model pengembangan yang digunakan merupakan adaptasi model Borg \& Gall. Produk yang telah dikembangkan ini sebagai bahan pembelajaran Mata Kuliah Berbicara dan Pembelajarannya. Berdasarkan hasil uji coba awal, modul praktik berbicara dengan metode jigsaw ini memperoleh skor 4,00 dari segi tampilan, 4,3 dari segi materi, dan 4,00 dari segi manfaat.

\section{DAFTAR PUSTAKA}

Azmi, S. R. M. (2019). Peningkatan Keterampilan Berbicara Menggunakan Metode Bercerita Siswa Kelas V Sekolah Dasar. Journal of Science and Social Research, 2(1), 7-11.

Borg, W. R. and Gall, M. D. (1983). Educational Research An Introduction. Fourth Edition. New York \& London: Longman.

Darmuki, A., \& Hariyadi, A. (2019). Peningkatan Keterampilan Berbicara Menggunakan Metode Kooperatif Tipe Jigsaw pada Mahasiswa PBSI Tingkat IB IKIP PGRI Bojonegoro Tahun Akademik 2018/2019. KREDO: Jurnal Ilmiah Bahasa dan Sastra, 2(2), 256-267.

Ghazali, S. (2010). Pembelajaran keterampilan berbahasa dengan pendekatan komunikatifinteraktif. Bandung: Refika Aditama.
Berdasarkan hasil uji coba awal juga, modul praktik berbicara dengan metode jigsaw ini termasuk bahan ajar yang berklasifikasi baik dan berdasarkan saran dari validator materi dan validator desain (penyajian) sehingga modul praktik berbicara ini siap diujicobakan pada mata kuliah Berbicara dan Pembelajarannya. Tanggapan mahasiswa terhadap modul ini bahwa mereka merasa percaya diri dan termotivasi untuk melakukan praktik berbicara, khususnya praktik pidato, khotbah, pembawa acara, dan debat.

Hanafiah \& Suhana. (2012). Konsep Strategi Pembelajaran. Bandung: PT. Refrika Aditama.

Mudhlofar, A. (2012). Aplikasi Pengembangan Kurikulum Tingkat Satuan pendidikan dan Bahan Ajar dalam Pendidikan Islam. Jakarta: Rajawali press.

Prastowo, A. (2015). Panduan Kreatif Membuat Bahan Ajar Inovatif. Yogyakarta: Diva Press.

Sugiyono. (2013). Metode Penelitian Kuantitatif Kualitatif dan R\&D. Bandung: Alfabeta.

Warsono \& Hariyanto. (2012). Pembelajaran Aktif Teori dan Asesmen. Bandung: Remaja Rosda Karya.

Yamin, M. (2013). Strategi \& Metode dalam Pembelajaran. Jakarta: GP Press Grup 
114 JURNAL PENDIDIKAN EDUTAMA, Vol.8, No.1 Januari 2021 